\title{
THE EFFECTIVENESS OF POLAR AND NON POLAR FRACTIONS OF AGERATUM CONYZOIDES L. TO CONTROL PEANUT RUST DISEASE AND PHYTOCHEMICAL SCREENINGS OF SECONDARY METABOLITES
}

\author{
Eriyanto Yusnawan \\ Indonesian Legumes and Tuber Crops Research Institute \\ Jl. Raya Kendalpayak Km 8, Kotak Pos 66 Malang, East Java 65101 \\ E-mail: yusnawan@yahoo.com
}

\begin{abstract}
The effectiveness of polar and non-polar fractions of Ageratum conyzoides L. to control peanut rust disease and phytochemical screenings of secondary metabolites. Peanut rust disease caused by Puccinia arachidis is one of the important diseases which causes yield loss more than $50 \%$. An alternative control which is more environmentally friendly can be conducted by applying botanical fungicides extracted from weeds. This study aimed to obtain effective concentrations of polar and non-polar fractions of roots, leaves, and flowers of Ageratum conyzoides as well as to investigate secondary metabolites in each extract. A spore germination test was conducted to determine the effectiveness of each extract. An application of $5 \%$ polar fraction of the leaves resulted $98 \pm 2 \%$ ungerminate spores which was not different with the application of $5 \%$ polar fraction of the roots which resulted $95 \pm 2 \%$ ungerminate spores. The use of a polar solvent extracted more diverse secondary metabolites compared with that of a non-polar solvent. Phytochemical screening tests on the three extracts showed that the leaf polar fraction contained more diverse secondary metabolites as compared with the others. The polar fraction of the leaves contained alkaloids, flavonoids, tannins, saponins, and terpenoids. A further test to confirm the existence as well as to separate these compounds with thin layer chromatography showed that alkaloids, flavonoids, saponins, and terpenoids separated into 7, 9, 6, and 8 spots, respectively. These secondary metabolites may be responsible to inhibit the spore germination of $P$. arachidis.
\end{abstract}

Key words: Ageratum conyzoides, botanical fungicide, peanut rust disease, secondary metabolite

\begin{abstract}
ABSTRAK
Efektivitas fraksi polar dan non polar Ageratum conyzoides L. untuk mengendalikan penyakit karat kacang tanah dan skrining fitokimia metabolit sekunder. Penyakit karat kacang tanah yang disebabkan oleh Puccinia arachidis merupakan salah satu penyakit penting yang mampu menurunkan hasil polong hingga lebih dari 50\%. Pengendalian ramah lingkungan dilakukan salah satunya dengan aplikasi fungisida nabati dari ekstrak gulma. Penelitian bertujuan untuk mendapatkan konsentrasi efektif fraksi polar dan non polar dari akar, daun, dan bunga Ageratum conyzoides dan mengetahui golongan senyawa metabolit sekunder yang terkandung dalam ekstrak gulma yang digunakan. Uji perkecambahan spora secara in vitro dilakukan untuk mengetahui keefektifan masing-masing ekstrak. Aplikasi fraksi polar daun dengan konsentrasi $5 \%$ menghasilkan spora yang tidak berkecambah sebanyak $98 \pm 2 \%$ yang hasilnya tidak berbeda dengan aplikasi $5 \%$ fraksi polar akar, yaitu $95 \pm 2 \%$ spora tidak berkecambah. Pelarut polar mampu mengekstrak lebih beragam metabolit sekunder dibandingkan dengan pelarut non polar. Skrining fitokimia awal yang dilakukan menunjukkan bahwa fraksi polar daun mengandung golongan metabolit sekunder yang lebih beragam dibandingkan bagian akar dan bunga. Fraksi polar daun mengandung alkaloid, flavonoid, tannin, saponin, dan terpenoid. Uji konfirmasi keberadaan metabolit sekunder dengan kromatografi lapis tipis untuk memisahkan golongan senyawa tersebut menunjukkan bahwa alkaloid, flavonoid, saponin, dan terpenoid masing-masing menghasilkan 7 , 9, 6, dan 8 noda. Kandungan metabolit sekunder tersebut diduga berperan dalam menggagalkan perkecambahan spora $P$. arachidis.
\end{abstract}

Kata kunci: Ageratum conyzoides, fungisida nabati, karat kacang tanah, metabolit sekunder

\section{INTRODUCTION}

Peanut rust disease caused by Puccinia arachidis Speg. is one of the important diseases which causes pod yield loss from $6 \%$ to $57 \%$ depending on the susceptibility of crops (Subrahmanyam \& McDonald, 1984). Favorable environment, especially temperature at around $25{ }^{\circ} \mathrm{C}$ and relative humidity more than $87 \%$ supports the infection and pustule development (Arsule \& Pande, 2011; Sunkad \& Kulkarni, 2007). Urediospores 
germinate to form germ tubes and penetrate host cells as initial infection (Saleh, 2010). The spread of this disease was supported by the wind and water splashing. In Indonesia, peanut rust disease spreads at the central productions of peanuts such as East Java, Bali, and West Nusa Tenggara (Semangun, 1991).

The effective treatment to control this disease is by carrying out integrated pest management (IPM). This approach involves the combination of one of the following components: the use of resistant varieties, alternative host eradication or sanitation, crop rotation, biological controls, and fungicide applications. The application of chemical fungicides as a component in the IPM has been proven effective to reduce infection rate, however, less environmental friendly. Natural fungicides extracted from plants could be considered to minimize intensive applications of the chemical fungicides. The extracts have been used as antimicrobial agents and anti insects because of the secondary metabolite contents, including flavonoids, alkaloids, terpenoids, saponins, and tannins (Harborne, 1998; Kamboj \& Saluuja, 2008; Patil et al., 2009).

A. conyzoides has been known as an invasive weed because of its fast growth and disturbing the growth of crops. The weed released allelochemical compounds which suppressed the crop growth (Kong, 2006). Since ancient era, the weed has been used to cure several human diseases such as skin diseases, skin wound, diseases caused by bacterial infections, and headache (Kamboj \& Saluuja, 2008). Extract of this weed also suppressed the growth of Candida albicans, Cryptococcus neoformans, Sclerotium rolfsii and Trichophyton mentagrophytes (Okunande, 2002).

Applications of this weed extract to control plant pathogens were still limited. Kong (2006) reported that essential oil of Ageratum which contained ageratochromones, monoterpepenoids, and sesquiterpenoids inhibited Rhizoctonia solani, Botryris cinerea, and $S$. rolfsii. However, studies on the application of Ageratum extract to control peanut rust disease have not been reported yet. Therefore, this study aimed to determine effective concentrations of the root, leaf, and flower extracts of Ageratum to suppress the growth of rust spores in vitro and to screen the secondary metabolites.

\section{MATERIALS AND METHODS}

Sample preparation and extraction. Ageratum weeds were collected from around Kendalpayak Research Station, Indonesian Legumes and Tuber Crops Research
Institute (ILETRI), Malang East Java. Roots, leaves, and flowers were separated, air dried, and ground to obtain fine particles. Maceration in methanol and $n$ hexane $(1: 10 \mathrm{w} / \mathrm{v})$ was conducted separately for $18 \mathrm{~h}$ after shaking the suspension using an orbital shaker for $4 \mathrm{~h}$ at $100 \mathrm{rpm}$. Supernatant was collected after filtration and extracts containing the solvents were evaporated using a vacuum rotary evaporator. The crude extracts were stored at $4^{\circ} \mathrm{C}$ in the dark before used (Agbafor and Nwachukwu, 2011; Yusnawan, 2013).

Spore germination test. Treatments were arranged in a completely randomized design with three factors and three replicates. The first factor was polarity of solvents used to extract samples (methanol as a polar solvent and $n$-hexane as a non polar solvent). The second factor was three parts of Ageratum (roots, leaves, and flowers), and the third factor was four concentration levels $(0.1 \%, 1 \%, 2.5 \%$, and $5 \%)$. Spores of $P$. arachidis were collected from 10-week infected crops cultivated in an ILETRI greenhouse. The infected leaves were harvested and incubated in petridishes for two days. The humidity was maintained at around $95 \%$ by placing wet cotton layers inside the petridishes. Mature spores were harvested and suspended in sterile water. Spore germination was tested in the polar and non polar crude extracts with four concentration levels. Phosphate buffer was used as the control. The numbers of germinate and ungerminate spores were recorded after $24 \mathrm{~h}$ of incubation (Yusnawan, 2013).

Phytochemical screening. The polar and non polar crude extracts were screened to determine the presence of alkaloids, flavonoids, tannins, saponins, and terpenoids according to a method developed by Trease \& Evans (1983). Briefly, alkaloids were detected using Mayer dan Wagner reagents. Sedimentation or precipitation on the bottom of the extracts showed positive results. Flavonoids were determined using $\mathrm{Mg}$ and $\mathrm{HCl}$. Red colour indicated the presence of flavonoids. Tannins were detected using $\mathrm{FeCl}_{3}$ and gelatin. Change in colour from light green to dark green or dark blue indicated the presence of tannins after being reacted with $\mathrm{FeCl}_{3}$ or white sedimentation after being added gelatin. Saponins were detected by the ability of the extracts to form foam for at least $30 \mathrm{~s}$ after shaking. Terpenoids were detected using Liebermann-Burchard reagent and $\mathrm{H}_{2} \mathrm{SO}_{4}$, and the presence of terpenoids was shown by reddish brown rings after being reacted with concentrated $\mathrm{H}_{2} \mathrm{SO}_{4}$ (Harborne, 1998; Trease and Evans, 1983). 
Separation of active compounds using thin layer chromatography (TLC). Separations of active compounds were performed on $\mathrm{F}_{254}$ silica gel plates. Crude extracts $(5 \mu \mathrm{l})$ were spotted on the plates and separated using suitable mobile phases. Methanol:chloroform $(0.5: 9.5 \mathrm{v} / \mathrm{v})$ was used to separate alkaloids (Wagner \& Bladt, 1996), chloroform:methanol $(9: 1 \mathrm{v} / \mathrm{v})$ to separate flavonoids (Harborne, 1998), $n$ hexane:acetone $(4: 1 \mathrm{v} / \mathrm{v})$ to separate saponins (Marliana et al., 2005), and $n$-hexane:ethyl acetate $(2: 8 \mathrm{v} / \mathrm{v})$ to separate terpenoids (Wagner \& Bladt, 1996).

\section{RESULTS AND DISCUSSION}

Spore germination test. The polar and non polar extracts of the roots, leaves, and flowers with four concentration levels were tested to determine the effectiveness of the extracts against spore germination of peanut rust. At the same concentration of the polar and non polar extracts, especially $1.0 \%$ and above, the polar extracts inhibited more germinate spores compared to those of the non polar extracts, for example $1.0 \%$ of the polar extract of the roots inhibited $77 \%$ of germinate spores, whereas the counterpart only inhibited $64 \%$ of germinate spores (Figure 1). The effective concentrations to inhibit spore germination were $5 \%$ of the polar fraction of the roots $(95 \pm 2 \%)$ and $5 \%$ of the polar fraction of the leaves $(98 \pm 2 \%)$. The numbers of germinate spores of these two extracts were only $5 \pm 2 \%$ and $2 \pm 2 \%$ for the root and leaf extracts. Interestingly, only the non polar fraction of the flowers resulted more ungerminate spores $(64 \pm 4 \%)$ than the polar fraction
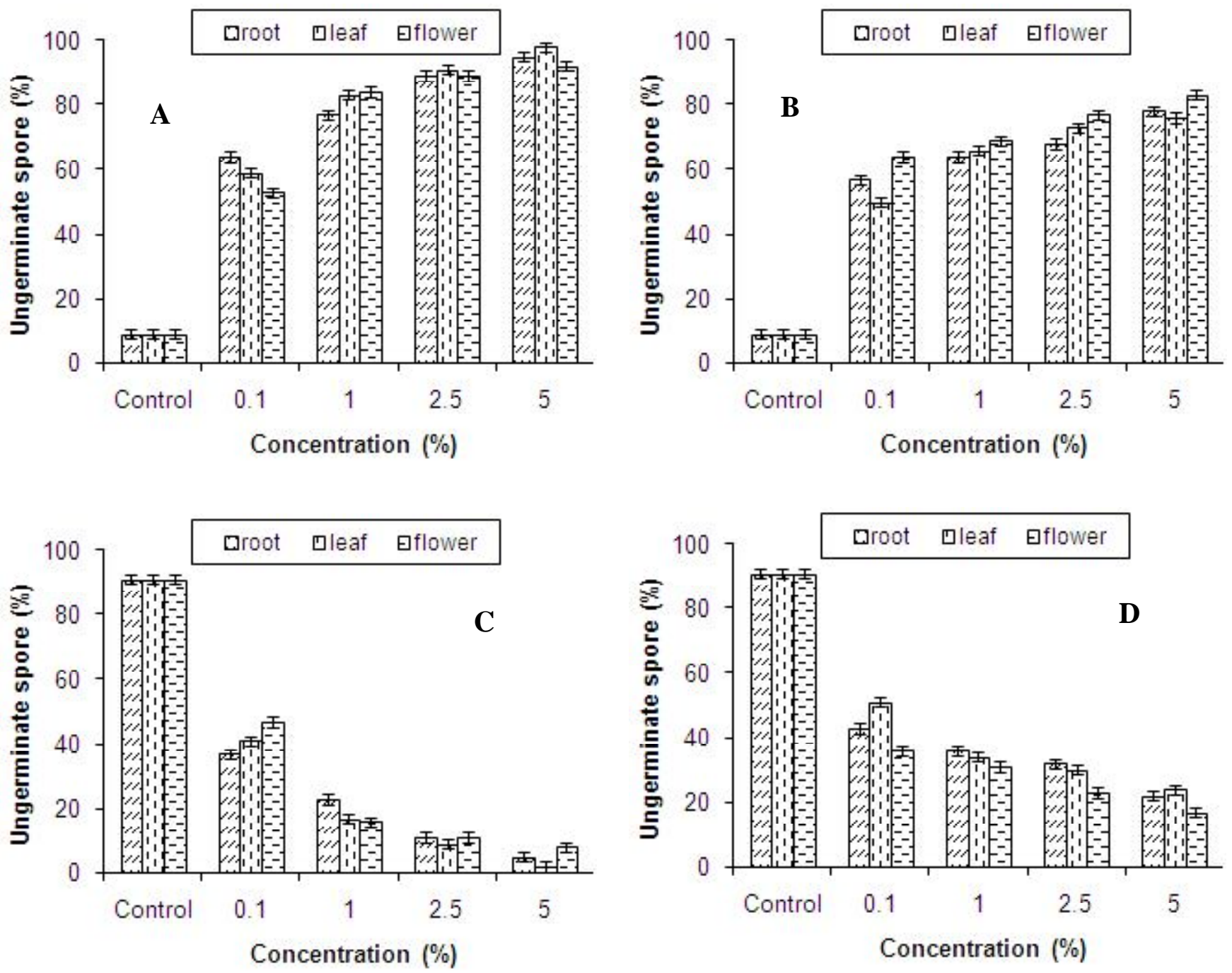

Figure 1. Percentages of ungerminate spores of $P$. arachidis treated with the polar fractions (A), ungerminate spores treated with the non polar fractions (B), and germinate spores treated with the polar fractions (C), germinate spores treated with the non polar fractions of A.conyzoides (D). Bars show deviation standards. 
$(53 \pm 2 \%)$, which was not observed in the non polar fractions of the roots and leaves at all concentration levels. Microscopic examination of ungerminate spores showed that the spores were either shrinking as indicated by the reduction of the spore size or lyses as indicated by the breakdown of the spore wall.

Crude extracts from plants extracted with polar solvents including methanol and other alcohol solvents showed more effective to inhibit fungal growth (Cimanga et al., 2004; Sharma et al., 2007). According to Sharma et al. (2007), the effectiveness of the methanol fraction extracted from Millingtonia hortensis as antifungal compounds showed stronger activities than those of less polar solvents, chloroform and ethyl acetate. In another study, the use of $80 \%$ methanol to extract Mitracarpus scaber leaves showed stronger inhibition to fungal growth than the use of $n$-hexane (Cimanga et al., 2004). In the case of the non polar fraction of Ageratum flowers inhibiting more germinate spore than the polar fraction, it may be related to the presence of essential oil in the flowers. According to Patil et al. (2009), essential oil of Ageratum which had reddish-orange in colour and a powerful odor constituted up to $0.18 \%(\mathrm{v} / \mathrm{w})$ of the macerated tissue. In addition, three main compounds of this essential oil, i.e. caryophyllene, precocene I (dimethoxi ageratocromene) and precocene II were effective to inhibit the growth of toxigenic strains of Aspergillus flavus and A. parasiticus (Nogueira et al., 2010; Patil et al., 2009).

The use of different solvents for extraction influenced compositions and groups of chemical compounds (Dehkharghanian et al., 2010). Polar solvents including alcohol groups were commonly used to extract organic compounds from natural products including plant secondary metabolites. The polar solvents were able to increase cell permeability and to penetrate inside the cells, therefore, extracting more endocellular secondary metabolites, both polar and less polar compounds compared to the use of non polar solvents, such as $n$-hexane (Cannell, 1998; Seidel, 2012). Non polar solvents only dissolved non polar compounds. The secondary metabolites of $A$. conyzoides extracted from the polar solvent may increase the effectiveness to inhibit $P$. arachidis spores as observed in this study.

Phytochemical screening. This study aimed to determine active compounds from the polar and non polar extracts of the roots, leaves, and flowers. Changes in colour of the extracts or sedimentation forms after being reacted with the suitable reagents were recorded to determine the presence of the active compound tested. The use of polar solvent for maceration resulted more diverse in the secondary metabolite groups as observed in Table 1. At least, five and two active compound groups were detected in the polar and the non polar extracts, respectively. The polar fraction of the leaves showed the most diverse in secondary metabolites compared to those of the other fractions. This fraction contained alkaloids, flavonoids, tannins, saponins, and terpenoids. The diverse compositions of these secondary metabolites may be responsible to inhibit spore germination of peanut rust. The polar fraction of the roots which had the same effectiveness as the polar fraction of the leaves to inhibit spore germination contained alkaloids, flavonoids, and terpenoids.

According to Seidel (2012), high polarity index of methanol was able to extract the secondary metabolites which had polar properties such as flavonoid glycosides, tannins, and several alkaloids. Also, this solvent was effective to extract phenolic compounds with low molecular weights and medium levels of polarity (Yu Lin et al., 2009), aglycons of flavonoids (Dehkharghanian et al., 2010), anthocyanins, terpenoids,

Table 1. Phytochemical screenings of the polar and non polar extracts of the roots, leaves, and flowers of A. conyzoides

\begin{tabular}{lcccccc}
\hline \multirow{2}{*}{ Active compound } & \multicolumn{3}{c}{ Polar fraction } & \multicolumn{3}{c}{ Non polar fraction } \\
\cline { 2 - 7 } & Root & Leaf & Flower & Root & Leaf & Flower \\
\hline Alkaloid & ++ & ++ & + & - & ++ & + \\
Flavonoid & ++ & ++ & ++ & - & - & - \\
Tannin & - & + & - & - & - & - \\
Saponin & - & + & - & ++ & - & - \\
Terpenoid & ++ & ++ & ++ & + & ++ & ++ \\
Steroid & - & - & - & - & - & - \\
\hline
\end{tabular}

++ showed more compound/dark colour, + showed less compound/light colour, - showed no compound detected. 
saponins, flavons, and polyphenolic compounds (Cowan, 1999). Non polar solvents such as $n$-hexane which had zero of polarity index only dissolved liphophilic compounds, including alcanas, waxes, colour pigments, sterols, several terpenoids and alkaloids, therefore, extracted less secondary metabolites.

Separation of secondary metabolites using TLC. Extracts which had the most effective inhibition to $P$. arachidis spores, i.e. the polar extracts of the leaves and roots were separated using TLC techniques. This study was conducted to confirm the presence of the active compounds as a further step after phytochemical screenings. Also, this step aimed to determine the number of active compounds of the secondary metabolites which were visualized as spots on the TLC plates.

In general, the numbers of spots found in the polar fraction of the leaves (Table 2) were more vary than those spots in the polar fraction of the roots (Table 3). However, more total numbers of the spots did not reflect more effective to inhibit the germinate spores and vice versa, as observed in this study when the effectiveness of the polar fractions of the leaves and the roots were compared. The concentration of each secondary metabolite group may contribute to the effectiveness of the extract rather than the spot numbers.

Table 2. Number of spots and secondary metabolite characteristics of the polar fraction of the leaves after separation using thin layer chromatography

\begin{tabular}{|c|c|c|c|c|}
\hline \multirow{2}{*}{ Secondary metabolite } & \multirow{2}{*}{ Number of spot } & \multirow{2}{*}{$\begin{array}{l}\text { Retardation factor/ } \\
\text { Rf value }(\mathrm{cm})\end{array}$} & \multicolumn{2}{|c|}{ Spot colour } \\
\hline & & & Visible light & UV light \\
\hline \multirow[t]{7}{*}{ Alkaloid } & 7 & 0.13 & Green & Brown \\
\hline & & 0.21 & Green & Brown \\
\hline & & 0.31 & No colour & Purple \\
\hline & & 0.37 & Yellow & Brown \\
\hline & & 0.53 & Dark yellow & Light purple \\
\hline & & 0.68 & Yellow & Dark purple \\
\hline & & 0.81 & Dark yellow & Light brown \\
\hline \multirow[t]{9}{*}{ Flavonoid } & 9 & 0.10 & Light red & Brown \\
\hline & & 0.18 & Light brown & Dark purple \\
\hline & & 0.31 & Dark green & Brown \\
\hline & & 0.33 & Light green & Brown \\
\hline & & 0.47 & Dark green & Dark yellow \\
\hline & & 0.60 & Yellow & Dark yellow \\
\hline & & 0.66 & No colour & Dark purple \\
\hline & & 0.72 & Green & Yellow \\
\hline & & 0.83 & Light green & Dark blue \\
\hline \multirow[t]{6}{*}{ Saponin } & 6 & 0.06 & Green & Purple \\
\hline & & 0.12 & Yellow & Yellow \\
\hline & & 0.21 & Light green & Purple \\
\hline & & 0.25 & Light green & Light yellow \\
\hline & & 0.37 & No colour & Purple \\
\hline & & 0.55 & No colour & Light purple \\
\hline \multirow[t]{8}{*}{ Terpenoid } & 8 & 0.23 & Dark yellow & Purple \\
\hline & & 0.30 & Green & Brown \\
\hline & & 0.33 & Dark green & Brown \\
\hline & & 0.46 & Green & Brown \\
\hline & & 0.61 & Yellow & Purple \\
\hline & & 0.71 & No colour & Dark purple \\
\hline & & 0.85 & No colour & Purple \\
\hline & & 0.88 & No colour & Dark blue \\
\hline
\end{tabular}


Table 3. Number of spots and secondary metabolite characteristics of the polar fraction of the roots after separation using thin layer chromatography

\begin{tabular}{lccll}
\hline \multirow{2}{*}{ Secondary metabolite } & \multirow{2}{*}{ Number of spot } & Retardation factor/ & \multicolumn{2}{c}{ Spot colour } \\
\cline { 3 - 4 } & & Rf value $(\mathrm{cm})$ & Visible light & UV light \\
\hline Alkaloid & 7 & 0.08 & Green & Purple \\
& 0.21 & No colour & Purple \\
& 0.25 & No colour & Brown \\
& 0.36 & No colour & Brown \\
& 0.61 & Yellow & Brown \\
& & 0.70 & No colour & Purple \\
Flavonoid & 0.82 & No colour & Light red \\
& & 0.66 & No colour & Brown \\
Saponin & 0.79 & No colour & Purple \\
Terpenoid & & 0.83 & No colour & Brown \\
& & - & - & - \\
& 4 & 0.42 & No colour & Purple \\
& & 0.48 & No colour & Purple \\
& & 0.77 & No colour & Purple \\
& & 0.87 & Yellow & Dark red \\
\hline
\end{tabular}

One of the main functions of plant secondary metabolites is for plant defense against pathogen infections (Vickery \& Vickery, 1981). With regards to the plant defense, alkaloids which were separated into 7 spots both in leaf and root extracts function to disturb components of peptidoglycans on the cells, therefore, the cell layers did not develop completely, resulting the death of the cells (Robinson, 1995). Alkaloids also inhibited cell respiration; inhibit esterase and DNA as well as RNA polymerases (Aniszewki, 2007). Flavonoids which were separated more spots in the leaf extract (9 spots) than in the root extract (3 spots) acted to form complex compounds on the extracellular protein which disturb cell membrane integrity and as protein coagulators. These active compounds also function as molecule signals and to protect plants against pathogen infections (Boue et al., 2009; Samantha et al., 2011).

In plants, saponins are carbohydrate deposits or waste products of plant metabolisms. Unfortunately, saponins were not detected in the root extract. Saponins are effective compounds to combat pathogens and pest insects since these chemicals have bitter properties. In addition, these compounds act as haemolysis agents and have ability to form complex compounds with cholesterols and other sisteroids (Robinson, 1995). Terpenoids are one of the phytoalexins, i.e. antimicrobial compounds produced by plants which are synthesized in higher amounts when the plants are infected by pathogens (Harborne, 1998; Cowan, 1999). According to Cowan (1999) and Das et al. (2010), tannins may disturb protein metabolism by forming hydrogen bonds, hydrophobic interactions, as well as covalent bonds. As a result, pathogens are unable to continue their growth normally. The compositions of alkaloids, flavonoids, tannins, saponins, and terpenoids in A. conyzoides may play an important role in inhibiting spore germination of $P$. arachidis, especially when polar fractions of roots and leaves at concentration of 5\% were applied.

\section{CONCLUSIONS}

The application of 5\% polar fractions of leaves and roots of $A$. conyzoides showed the highest result to inhibit spore germinations $(98 \pm 2 \%$ and $95 \pm 2 \%$, respectively), which may be potential to be utilized as botanical fungicides to suppress the infection rate of $P$. arachidis infected crops. Alkaloids, flavonoids, tannins, saponins, and terpenoids in the leaves which may be responsible to inhibit the spore germinations can be considered to be purified to determine the effectiveness of each purified compound.

\section{ACKNOWLEDGMENT}

Author thanks Tri Kustono Adi, M.Sc who gave suggestion during experiment and Sulistyowati, S.Si who helped this research. 


\section{REFERENCES}

Agbafor KN \& Nwachukwu N. 2011. Phytochemical analysis and antioxidant property of leaf extract of Vitex doniana and Mucuna pruriens. Biochem. Res. Internat. 2011: 1-4.

Aniszewski T. 2007. Alkaloid-Secrets of Life: Alkaloid Chemistry, Biological Significance, Applications and Ecological Role. Elsevier, Amsterdam.

Arsule CS. \& Pande BN. 2011. An aerobiological approach to groundnut rust. The Bioscan. 6(4): 563-566.

Boue SM, Cleveland TE, Carter-Wientjes C, Shih BY, Bhatnagar D, McLachlan JM, \& Burow ME. 2009. Phytoalexin-enriched functional foods. $J$. Agric. Food Chem. 57: 2614-2622.

Cannell RJP. 1998. Natural Products Isolation. Humana Press, Totowa.

Cimanga RK, Kambu K, Tona L,de Bruyne T, Sandra A, Totte J, Pieters L, \& Vlietinck AJ. 2004. Antibacterial and antifungal activities of some extracts and fractions of Mitracarpus scaber Zucc. (Rubiaceae). J. Nat. Remedies. 4(1): 1725.

Cowan MM. 1999. Plant products as anti-microbial agents. Clin. Microbiol. Rev. 12: 564-582

Das K, Tiwari RKS, \& Shrivastava DK. 2010. Techniques for evaluation of medicinal plant products as antimicrobial agent: Current methods and future trends. J. Med. Plants Res. 4(2): 104111.

Dehkharghanian M, Adenier H \& Vijayalakshmi MA. 2010. Analytical methods study of flavonoids in aqueous spinach extract using positive electrospray ionisation tandem quadrupole mass spectrometry. J. Food Chem. 121: 863-870.

Harborne JB. 1998. Phytochemical Methods: a Guide to Modern Techniques of Plant Analysis. $2^{\text {nd }}$ ed. Chapman and Hall, London.

Kamboj A \& Saluuja AK. 2008. Ageratum conyzoides L.: a review on its phytochemical and pharmacological profile. Internat. J Green Pharmacy. 2(2): 59-68.
Kong C. 2006. Allelochemicals from Ageratum conyzoides L. and Oryza sativa L. and their effects on related pathogens. In: Inderjit \& Mukerji KG (Eds). Allelochemicals: Biological Control of Plant Pathogens and Diseases. pp. 193-206. Springer. Netherlands.

Marliana SS, Suryanti V, \& Suyono. 2005. Skrining fitokimia dan analisis kromatografi lapis tipis komponen kimia buah labu siam (Sechium edule Jacq. Swartz.) dalam ekstrak etanol. Biofarmasi. 3: $26-31$.

Nogueira JHC, Goncalez E, Galleti SR, Facanali R, Marques MOM, \& Felicio JD. 2010. Ageratum conyzoides essential oil as aflatoxin suppressor of Aspergillus flavus. Internat. J. Food Microbiol. 137: 55-60.

Okunande AL. 2002. Ageratum conyzoides L. (Asteraceae). Fitoterapia. 73: 1-16.

Patil RP, Nimbalkar MS, Jadhav UU, Dawkar VV, \& Govindwar SP. 2009. Antiaflatoxigenic and antioxidant activity of an essential oil from Ageratum conyzoides L. J. Sci. Food Agric. 90(4): 608-614.

Robinson T. 1995. Kandungan Senyawa Organik Tumbuhan Tinggi. Diterjemahkan oleh Kosasih Padmawinata. ITB, Bandung.

Saleh N. 2010. Optimalisasi pengendalian terpadu penyakit bercak daun dan karat pada kacang tanah. Pengembangan Inovasi Pertanian. 3(4): 289-305.

Samantha A, Das G, \& Sanjoy KD. 2011. Roles of flavonoid in plants. Int. J. Pharm. Sci. Tech. 6(1): 12-35.

Seidel V. 2012. Initial and bulk extraction of natural product isolation. In: Sarker SD \& Nahar L (Eds). Natural Product Isolation, Methods in Molecular Biology. 864: 27 - 41.

Semangun H. 1991. Penyakit-penyakit Tanaman Pangan di Indonesia. Gajah Mada University Press, Yogyakarta.

Sharma M, Puri S, \& Sharma PD. 2007. Antifungal activity of Millingtonia hortensis. Indian J. Pharmaceutical Sci. 69: 599-601. 
Subrahmanyam P \& McDonald D. 1984. Groundnut rust disease: epidemiology and control. In: McDonald D, Subrahmanyam P, Wightman JA (Eds). Groundnut Rust Disease, Proceedings of a Discussion Group Meeting. pp. 27-39. ICRISAT Center, Patancheru. September 24-28, 1984.

Sunkad G \& Kulkarni S. 2007. Studies on perpetuation and carryover of groundnut rust (Puccinia arachidis Speg.) in Northern Karnataka. Karnataka J. Agric. Sci. 20(2): 297-300.

Trease GE \& Evans WC. 1983. Pharmacognosy. 12 ${ }^{\text {th }}$ ed. Bailliere Tindall Press, London.

Vickery ML \& Vickery B. 1981. Secondary Plant Metabolism. The Macmillan Press, London.
Wagner H \& Bladt S. 1996. Plant Drug Analysis: a Thin Layer Chromatography Atlas. Springer, Germany.

Yu Lin H, Kuo YH, Lin YL, \& Chiang W. 2009. Antioxidative effect and active component from leaves of lotus (Nelumbo nucifera). J Agric. Food Chem. 57: 6623-6629.

Yusnawan E. 2013. Skrining golongan senyawa aktif fraksi polar Amaranthus spinosus dan efektivitasnya terhadap penyakit karat daun kacang tanah in vitro. Dalam Purnomo J, Harisudin M, Praseptiangga D, Magna A, Rahayu, Widiyanto, Indreswari R, Yanti Y, Hertanto BS (Eds). Prosiding Sem Nas Akselerasi Pembangunan Pertanian Berkelanjutan Menuju Kemandirian Pangan dan Energi. Pp. 377-382. UNS, Surakarta Oktober, 2013. 